Scientia Agricola

http://dx.doi.org/10.1590/0103-9016-2014-0130

\title{
Breeding common bean populations for traits using selection index
}

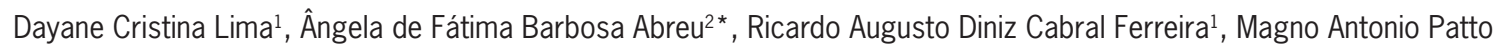 \\ Ramalho ${ }^{1}$
}

\begin{abstract}
'Federal University of Lavras - Dept. of Biology/Genetics and Plant Breeding, C.P. 3037 - 37200-000 - Lavras, MG - Brazil.

2Embrapa Rice and Beans, Rod. G0-462, km 12, C.P.179

- Zona Rural - 75375-000 - Santo Antônio de Goiás, GO Brazil.

*Corresponding author <afbabreu@dbi.ufla.br>
\end{abstract}

Edited by: Leonardo Oliveira Medici

Received April 03, 2014

Accepted July 18, 2014

\begin{abstract}
A common bean (Phaseolus vulgaris L.) cultivar must combine desirable genotypes for several traits in order to be accepted by producers and consumers. This study aimed to evaluate selection efficiency when segregating bean populations for traits, by means of a selection index, in order to obtain superior progenies for traits considered. A total of 16 populations from the $F_{4}$ and $F_{5}$ generations were evaluated in 2011 and 2012, respectively. The traits evaluated were plant architecture, plant disease, grain type and yield. Using standard scores (Z), the sum of the four traits $(\Sigma Z)$ was obtained and, based on this information, the best populations were identified. The evaluation of selection effectiveness was performed on 31 progenies from each population. The 496 progenies plus eight controls were evaluated in the $F_{5: 6}$ and $F_{5: 7}$ generations for the same traits in July and November 2012, respectively. The selection, using the index based on the sum of standardized variables $(\Sigma \mathrm{Z})$, was efficient for identifying populations with superior progenies for all the traits considered. Keywords: plant architecture, plant disease, grain yield
\end{abstract}

\section{Introduction}

Common bean (Phaseolus vulgaris L.) is one of the main crops in Brazil. A common bean cultivar must combine desirable genotypes for several traits in order to be accepted by producers and consumers. For producers, it must have high grain yield, good plant architecture, resistance to the main pathogens and a highly marketable grain type. On the other hand, consumers are interested only in the traits related to grain quality. Therefore, the main breeding programs that work with the common bean crop in Brazil have devoted great effort to obtaining lines that meet all the goals mentioned (Abreu et al., 2007; Melo et al., 2010 and Pereira et al., 2012).

It is necessary to generate enough variability to increase the probability of successful selection in common bean (Fouilloux and Bannerot, 1988; Singh, 1995 and Singh and Urrea, 1995). To achieve this goal it is desirable to use highly divergent parents which are not adapted to the desirable growing conditions. Under these conditions, the probability of obtaining a line better than those that already exist is quite small (Abreu et al., 2002). Thus, for advantages to be accumulated over the years the best alternative is to make a cross between lines with proven higher performance for the desirable traits (Rasmusson and Phillips, 1997). The challenge is to identify segregating populations that combine high average and sufficient genetic variability to carry on a breeding process based on crosses between superior lines.

When combining various traits in selection, an interesting choice is the use of a selection index. Many methods of obtaining a selection index can be found in the literature (Bernardo, 2010), and the sum of standardized variables $\left(\sum Z\right)$ has been greatly used in common bean crop (Lima et al., 2012). However, this index has not yet been used to select segregating populations that combine various traits.

To verify the efficiency of the choice of population, an alternative is to evaluate the progenies derived from it and verify if there is coincidence in the selection of populations and progenies. This study aimed to evaluate the selection efficiency in segregating bean populations for various traits, using a selection index, in order to obtain the superior progeny for traits considered.

\section{Materials and Methods}

The study was conducted in Lavras, in the state of

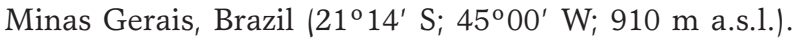
A total of 16 segregating populations obtained from the Common Bean Breeding Program of the Brazilian Corporation of Agricultural Research (Embrapa). Rice and Beans (Table 1) were used, in which all the parents were carioca-type grains and most were cultivars released or in a releasing phase. These populations were evaluated in the $\mathrm{F}_{4}$ and $\mathrm{F}_{5}$ generations. A randomized block experimental design was used with four replications and plots of two four-meter rows in the $\mathrm{F}_{4}$ generation and triple lattice with plots of four four-meter rows in the $\mathrm{F}_{5}$ generation. Crop management was as recommended for the common bean crop in the region (Barbosa and Gonzaga, 2012).

The following traits were considered in the evaluation: grain yield; plant architecture, evaluated on a scoring scale from 1 to 9 , in which the score of 1 was attributed to prostrate plants and the score of 9 to completely upright plants; plant disease, evaluated on a scoring scale from 1 to 9 in which 1 was attributed to plants with severe disease symptoms and 9, total absence of diseases; grain type, evaluated on a scoring scale from 1 to 9 in which the score 9 indicated carioca type grain 
Table 1 - Common bean populations used in obtaining progenies.

\begin{tabular}{lc}
\hline Populations & Identification \\
\hline 1 & CNFC 8063 / BRS Cometa \\
2 & CNFC 8063 / BRSMG Majestoso \\
3 & CNFC 8063 / GX 9792-299-2 \\
4 & BRS Estilo / BRS Cometa \\
5 & BRS Estilo / CNFC 8075 \\
6 & BRS Estilo / BRSMG Majestoso \\
7 & BRS Estilo / GX 9792-299-2 \\
8 & BRS Estilo / CNFC 9506 \\
9 & BRS Cometa / CNFC 8075 \\
10 & BRS Cometa / Guará \\
11 & BRS Cometa / BRSMG Majestoso \\
12 & BRS Cometa / CNFC 10269 \\
13 & Guará / GX 9792-299-2 \\
14 & Guará / CNFC 10269 \\
15 & BRSMG Majestoso / GX 9792-299-2 \\
16 & BRSMG Majestoso / CNFC 10269
\end{tabular}

(beige with brown stripes) in which the hue of the beige color and of the brown stripes were very light, without a colored halo around the hilum, with a mean weight of 100 seeds around $27 \mathrm{~g}$, and grains not flattened, and 1 referred to the carioca type grain outside of the commercial standard mentioned.

The data obtained in the evaluation of each trait were initially subjected to individual analysis of variance, per crop season (or generation). Afterwards, data from each plot were standardized, obtaining the $Z_{i j l}$ value by means of the expression $Z_{i j l}=\left(Y_{i j l}-\bar{Y}_{. j l}\right) / s_{. j l}$, in which $Z_{i j l}$ is the value of the standardized variable corresponding to trait $l$ in population $i$ in replication $j_{i} Y_{i j l}$ is observation of trait $l$ of population $i$ in replication $j_{i}{ }_{i} \bar{Y}_{. j l}$ is the overall mean of trait $l$ in replication $j_{i}$ and $\mathrm{s}_{j l}$ is phenotype standard deviation of trait $l$ in replication $j$. To avoid the occurrence of negative values, the constant four was added to the $Z_{i j}$ values. After standardization of the variables, the sum of $Z_{i j l}$ was obtained per plot by the following expression: $Z_{i j}=\sum_{i j}^{4} z_{i j} . \sum Z$ was also subjected to analysis of variance per ${ }_{l=1}$ crop season. Subsequently, joint analysis of variance of all the traits and $\Sigma \mathrm{Z}$ index was made. The mean values of the populations were clustered using the Scott and Knott (1974) test.

In the $\mathrm{F}_{5}$ generation, 31 individual plants were collected from each population, which constituted the progenies which were evaluated in the $\mathrm{F}_{5: 6}$ and $\mathrm{F}_{5: 7}$ generations, sown in Jul. and Nov. 2012, respectively. The $496 \mathrm{~F}_{5: 6}$ progenies were evaluated in two adjacent experiments, together with eight common controls (BRS Cometa, BRSMG Majestoso, BRS Estilo, BRS Notável and Pérola cultivars, and CNFC8063, CNFC8075 and RP-1 lines). Each experiment was composed of 256 treatments (248 progenies and the eight controls). A $16 \times 16$ simple lattice design was used and the plots were two-meter rows spaced at $0.5 \mathrm{~m}$. The same procedure was adopted for the $\mathrm{F}_{5: 7}$ generation, except for the plot size, which was two two-meter rows spaced at $0.5 \mathrm{~m}$.
The same traits used in evaluation of the populations were considered. The data were also standardized and, subsequently, the $\sum Z$ index was obtained. In the same way that the populations were evaluated, a constant was added to the $\mathrm{Z}$ values to avoid the occurrence of negative values. The data from each trait evaluated and $\sum \mathrm{Z}$ index were subjected to individual analysis of variance. Based on individual analyses within each crop season, an analysis of groups of experiments with common controls was made in accordance with Ramalho et al. (2012), considering the two experiments. Afterwards, joint analysis of the two generations/crop seasons was carried out using the adjusted mean values.

Considering all the progenies, regardless of the population, gain expected from selection $\left(\mathrm{GS}_{\mathrm{X}}\right)$ was estimated for the traits and $\sum \mathrm{Z}$ by selecting of the 50 best progenies. It was also estimated the correlated response in each trait $(\mathrm{Y})$ by selection made in the trait $\mathrm{X}\left(\mathrm{RC}_{\mathrm{Y}(\mathrm{X})}\right)$ (Ramalho et al., 2012).

\section{Results}

Differences between populations within the two generations for all traits were evident $(p<0.05)$. The population $\times$ environment interaction was also significant, except for plant architecture. The populations were compared using the Scott and Knott (1974) test considering the mean of the two crop seasons (Table 2). Populations $4,5,7$ and 8 had the best performance based on the

Table 2 - Mean values of plant architecture, plant disease, and grain type scores, grain yield $\left(\mathrm{kg} \mathrm{ha}^{-1}\right)$ and $\mathrm{Z}$ index $(\Sigma \mathrm{Z})$ obtained in evaluation of common bean populations (Pop) in Lavras, MG, Brazil, in the $\mathrm{F}_{4}$ and $\mathrm{F}_{5}$ generations.

\begin{tabular}{|c|c|c|c|c|c|}
\hline Pop & $\begin{array}{c}\text { Plant } \\
\text { Architecture }\end{array}$ & $\begin{array}{c}\text { Plant } \\
\text { Disease }^{(b)}\end{array}$ & Grain Type ${ }^{(\mathrm{c})}$ & Yield & $\Sigma Z$ \\
\hline 1 & $4.9 b^{(d)}$ & $3.0 \mathrm{c}$ & $4.9 b$ & 3201 a & $13.9 \mathrm{c}$ \\
\hline 2 & $6.5 \mathrm{a}$ & $4.0 \mathrm{~b}$ & $6.1 \mathrm{a}$ & 3317 a & $17.1 \mathrm{~b}$ \\
\hline 3 & $6.1 \mathrm{a}$ & $4.3 b$ & $6.8 \mathrm{a}$ & 3028 b & $16.8 \mathrm{~b}$ \\
\hline 4 & $7.2 \mathrm{a}$ & $5.3 \mathrm{a}$ & $6.6 \mathrm{a}$ & 3356 a & $19.2 \mathrm{a}$ \\
\hline 5 & $6.3 \mathrm{a}$ & $4.8 \mathrm{a}$ & $7.1 \mathrm{a}$ & 3338 a & $18.1 \mathrm{a}$ \\
\hline 6 & $5.8 \mathrm{~b}$ & $3.4 \mathrm{c}$ & $4.8 b$ & $2791 \mathrm{c}$ & $14.0 \mathrm{c}$ \\
\hline 7 & $5.5 b$ & $5.2 \mathrm{a}$ & $8.2 \mathrm{a}$ & 3060 b & $18.5 \mathrm{a}$ \\
\hline 8 & $7.3 \mathrm{a}$ & $5.2 \mathrm{a}$ & $6.6 \mathrm{a}$ & 3373 a & $19.5 \mathrm{a}$ \\
\hline 9 & $6.2 \mathrm{a}$ & $4.2 \mathrm{~b}$ & $6.2 \mathrm{a}$ & 3220 a & $16.6 \mathrm{~b}$ \\
\hline 10 & $5.8 \mathrm{~b}$ & $3.2 \mathrm{c}$ & $4.1 \mathrm{~b}$ & 3351 a & $14.8 \mathrm{c}$ \\
\hline 11 & $6.3 \mathrm{a}$ & $4.3 b$ & $5.0 \mathrm{~b}$ & $2806 \mathrm{c}$ & $15.3 \mathrm{c}$ \\
\hline 12 & $4.8 b$ & $3.3 c$ & $4.4 b$ & $2629 d$ & $12.5 \mathrm{~d}$ \\
\hline 13 & $4.8 \mathrm{~b}$ & $3.3 \mathrm{c}$ & $6.3 \mathrm{a}$ & $3310 \mathrm{a}$ & $15.6 \mathrm{c}$ \\
\hline 14 & $5.2 \mathrm{~b}$ & $3.1 \mathrm{c}$ & $5.2 b$ & $2872 \mathrm{c}$ & $14.0 \mathrm{c}$ \\
\hline 15 & $6.4 \mathrm{a}$ & $4.0 \mathrm{~b}$ & $6.5 \mathrm{a}$ & $2511 d$ & $15.5 \mathrm{c}$ \\
\hline 16 & $5.1 \mathrm{~b}$ & $3.3 c$ & $6.1 \mathrm{a}$ & 3037 b & $14.7 \mathrm{c}$ \\
\hline
\end{tabular}

(a) Scores from 1 to 9 in which 1 indicates prostrate plants and 9 completely upright plants; (b) Scores from 1 to 9 in which 1 indicates plants with severe disease symptoms and 9 absence of diseases; ${ }^{(c)}$ Scores from 1 to 9 , in which 9 indicates carioca type grain and 1 carioca type grain outside of the commercial standard; (d)Values followed by the same letter in a single column belong to the same group (Scott and Knott test, $p<0.05$ ). 
$\sum \mathrm{Z}$ index and also for each trait individually. Population 7 was an exception, which showed lower performance for plant architecture. The performance of these populations combined the four standardized traits which are depicted in Figure 1. In this diagram, the dotted line represents the mean value and it is easy to identify in which traits each population showed higher or lower performance than the mean value.

The progeny evaluation showed differences $(p<$ $0.00)$ for plant architecture, grain type and $\Sigma Z$. The effect of the crop season $x$ treatment interaction, crop season $\mathrm{x}$ progenies interaction and crop season $\mathrm{x}$ population interaction was significant $(p \leq 0.01)$ for all traits, indicating the lack of coincidence of behavior among the crop seasons, which is in agreement with order studies (Lima et al., 2012 and Torga et al., 2013).

Observing the percentage of progenies among the 50 best for each trait and for all in combination, the best progenies derived from the best populations. This was mainly for traits that shown significant correlation among populations and the progenies derived from them: plant architecture score $(\mathrm{r}=0.67)$, yield ( $\mathrm{r}$

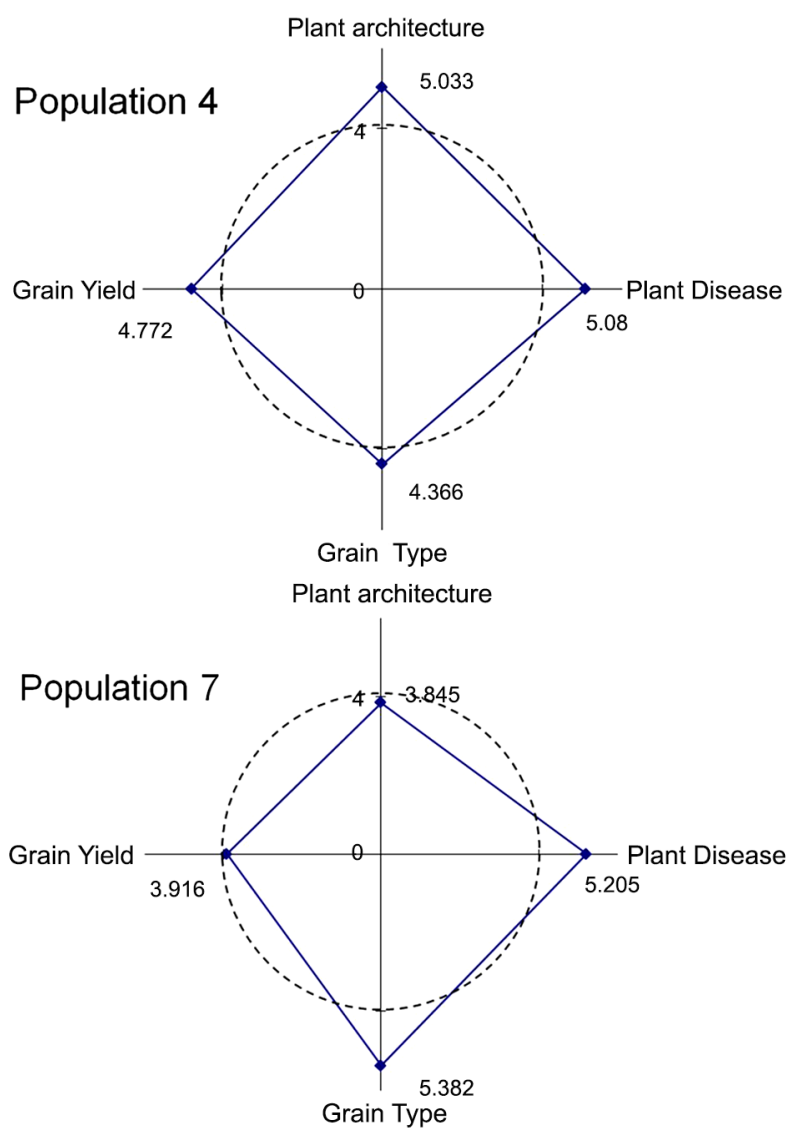

$=0.65)$ and $\sum Z(r=0.72)$ (Table 3). Regarding the 50 best progenies in the mean value of the crop seasons, 80 $\%$ for plant architecture score, $66 \%$ for $\sum \mathrm{Z}$ score, $38 \%$ for grain yield, $34 \%$ for plant disease score and $30 \%$ for grain type score came from populations 4, 5, 7 and 8. All the progenies among the 50 best were superior compared the controls.

The gain expected from selection for each trait $\left(G_{X}\right)$ was also estimated through the selection of the 50 best progenies for each trait and through the combination of selection for all four traits. Furthermore, the correlated response in each trait through selection in another $\left(\mathrm{RC}_{\mathrm{Y}(\mathrm{X})}\right)$ was also estimated. The estimates of the $\mathrm{GS}_{\mathrm{X}}$ had high values, especially for grain type score, in the mean value of joint analysis and in all the generations (Table 4). For grain yield, in which the progeny x crop season interaction was high, although the gains may be considered high in each crop season, in the mean value of the crop seasons, it was null. When selection was performed for the four traits simultaneously $(\Sigma \mathrm{Z})$, the gain from selection was positive and higher for all the others, except for grain yield in the mean of the crop seasons.
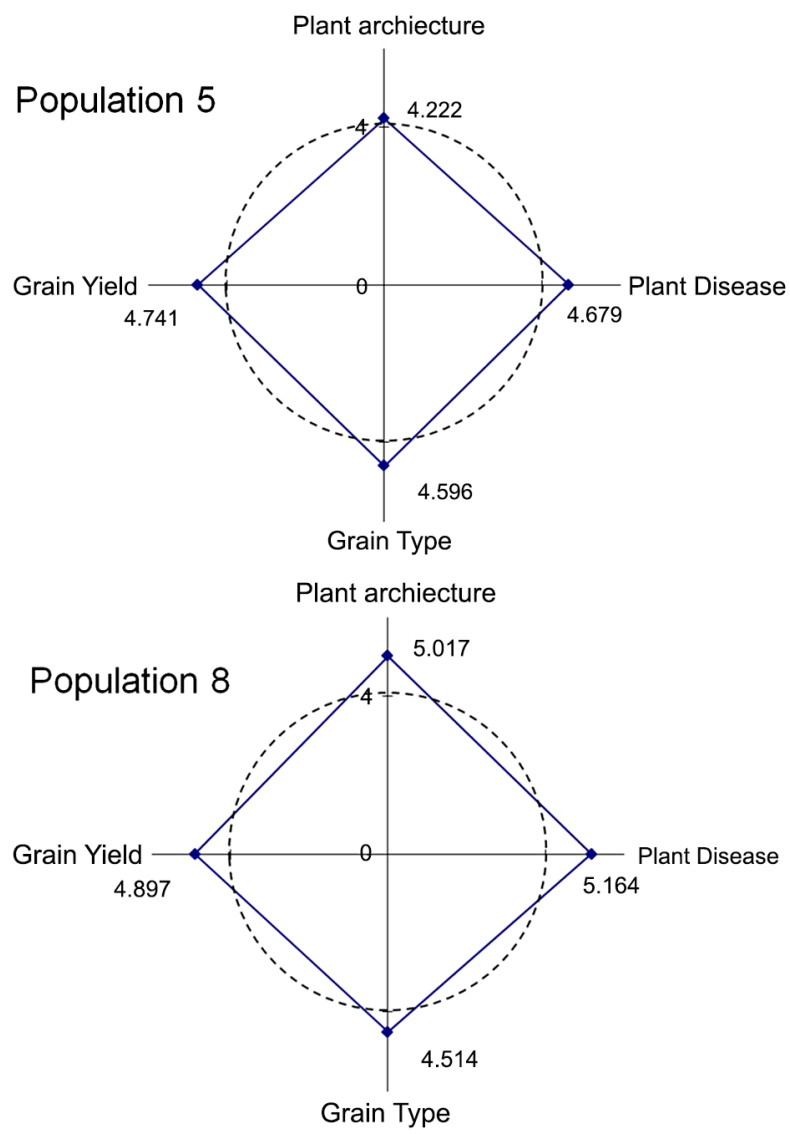

Figure 1 - Diagram of the standardized values of scores for plant architecture, plant disease, grain type and grain yield of the populations that showed greater estimates of $\Sigma \mathrm{Z}$. The dotted line represents the standardized mean added of the constant four. Each vertex corresponds to a trait. When it is above the line means that the population is superior for the trait. 
Table 3 - Percentage of common bean progenies among the 50 best of each population for the plant architecture, plant disease, and grain type scores and grain yield and the sum of all the standardized variables $(\Sigma Z)$ in the mean of the two generations (sowing time).

\begin{tabular}{lccccc}
\hline Population & $\begin{array}{c}\text { Plant } \\
\text { architecture }\end{array}$ & $\begin{array}{c}\text { Plant } \\
\text { disease }\end{array}$ & $\begin{array}{c}\text { Grain } \\
\text { type }\end{array}$ & Yield & $\Sigma Z$ \\
\hline 1 & 0 & 6 & 0 & 14 & 0 \\
2 & 0 & 20 & 0 & 12 & 4 \\
3 & 12 & 14 & 4 & 12 & 14 \\
4 & 30 & 12 & 2 & 18 & 22 \\
5 & 2 & 8 & 10 & 10 & 8 \\
6 & 4 & 14 & 0 & 10 & 8 \\
7 & 22 & 4 & 12 & 6 & 20 \\
8 & 26 & 10 & 6 & 4 & 16 \\
9 & 0 & 2 & 0 & 0 & 0 \\
10 & 0 & 2 & 0 & 4 & 0 \\
11 & 2 & 4 & 0 & 2 & 0 \\
12 & 0 & 0 & 16 & 0 & 0 \\
13 & 0 & 4 & 12 & 4 & 6 \\
14 & 0 & 0 & 34 & 4 & 0 \\
15 & 2 & 0 & 0 & 0 & 2 \\
16 & 0 & 0 & 4 & 0 & 0 \\
\hline
\end{tabular}

This is indicative of the advantage in use of the $\sum \mathrm{Z}$ index when the aim is to obtain progenies joining genotypes which are favorable for various traits.

\section{Discussion}

It is necessary to generate a great amount of variability in order to achieve success in selection in common bean (Nienhuis and Singh, 1988; Singh, 1995; Singh and Urrea, 1995). In this study, even though the variability generated is not high when only superior lines are crossed, it is still sufficient to obtain superior progenies. This observation is highly relevant since several common bean cultivars of excellent performance have already been obtained and recommended for the Brazilian common bean crop (Barbosa and Gonzaga, 2012). Thus, it is important that parents be used as was the case in this study, to reap the above mentioned advantages. In this study, the challenge was to obtain populations that had sufficient variability for selection and maintained an average high enough for all traits.

Whenever possible, the ideal is the early identification of the best segregating populations and select progenies from these populations in order to maximize efficiency from selection and to obtain greater gain. There are many alternatives for early population selection (Baenziger and Peterson, 1991; Griffing, 1956; Jinks and Pooni, 1976; Johnson and Winchern, 1998 and Ramalho et al., 2012). All of them would be efficient if the genotype $x$ environment interaction (GE), in this case the crop season or crop year, were not significant. An alternative would be to evaluate the populations at the time of bulk management and obtain progenies only from the best. However, in this case, the GE interaction may also reduce efficiency. In this study, we tried to evaluate this strategy. Thus, it was possible to identify if the populations with best performance contributed to obtaining the best progenies (Table 3).

Although progeny $\times$ generation/crop season interaction and populations $\mathrm{x}$ generation/crop season interaction has been detected, in most cases, selection of the populations would be very effective (Table 3). In a situation like this, instead of evaluating 31 progenies from each one of the 16 populations, the crop breeder would be able to evaluate, with the same work, 124 progenies from the four with best $\sum \mathrm{Z}$. The efficiency would be greater because, with 31 progenies, the variation range is 4.1 standard deviations. But with 124 progenies, the number arrived at is approximately five (Steel et al., 1997). This result is in agreement with Wricke and Weber (1986) who evaluated simulations and recommended that when heritability is low, a fact which occurred in many situations in this study (data not shown), the number of progenies should be increased at the expense of the number of crosses. Thus, a good strategy would be to evaluate the available populations in the greatest number of environments possible in order to select the greatest number of progenies from those that are identified as most promising.

When applying a selection index, a weighting can be designated for each variable. In this study, the option chosen was to give all four variables the same weight. That way, it was possible to identify which trait most contributed to success from the choice of progenies. The plant architecture score was the trait highly associated with the index (Table 3). Moreover, it may be observed that the parent BRS Estilo was involved in three (populations 4,7 and 8 ) out of the four best populations when the best performing progenies were considered. The performance of this parent is explained, above all, by good plant architecture (Melo et al., 2010), which was transferred to its descendents. When the index was used, one or more of the traits may have been negatively affected. In this case, it was grain type.

To confirm these observations, the $\mathrm{GS}_{\mathrm{X}}$ was estimated through selection of the 50 best progenies for each trait and through combined selection for the four traits as well as the correlated response $\left(\mathrm{RC}_{\mathrm{Y}(\mathrm{X})}\right)$. The estimates varied along with the trait and generation/crop season (Table 4). In the average of the crop seasons, the estimates were always less, due to progeny $\mathrm{x}$ crop season interaction. Nevertheless, the point of interest is the mean value because it is expected to have greater effect in future generations. Individually, gains for each trait were highly variable. For the grain type score and plant architecture score, the GS was high in the mean value of the generations and in all generations. For grain yield, in which the progeny $\times$ crop season interaction was higher, although the gains may be considered high in each crop season, in the mean value of the crop seasons, it was zero. Nevertheless, the selection undertaken in the index exhibited positive correlated responses in all traits, except for grain yield, because for 
Table 4 - Gain expected from selection in trait $X\left(G S_{X}\right)$ on the diagonal and correlated response in trait $Y\left(R C_{Y(X)}\right)$, outside of the diagonal, in percentage of the mean, with selection of the 50 best common bean progenies. Estimates obtained per generation (sowing time) and in mean value.

\begin{tabular}{|c|c|c|c|c|c|}
\hline \multirow{3}{*}{$\begin{array}{l}\text { Selected } \\
\text { Trait (X) }\end{array}$} & \multicolumn{5}{|c|}{ Response in trait $Y$} \\
\hline & Plant architecture & Plant disease & Grain type & Yield & $\Sigma \mathrm{Z}$ \\
\hline & \multicolumn{5}{|c|}{$F_{5.6}$ generation } \\
\hline Plant architecture & 12.61 & 2.01 & -9.64 & 13.33 & 5.88 \\
\hline Plant disease & 5.07 & 5.85 & -3.45 & 13.99 & 6.55 \\
\hline Grain type & -4.23 & -2.07 & 91.04 & -6.53 & 1.80 \\
\hline Yield & 2.65 & 2.00 & -3.80 & 39.34 & 7.00 \\
\hline \multirow[t]{2}{*}{$\Sigma \mathrm{Z}$} & 7.82 & 4.12 & 27.41 & 28.10 & 10.12 \\
\hline & \multicolumn{5}{|c|}{$\mathrm{F}_{5.7}$ generation } \\
\hline Plant architecture & 26.71 & 0.75 & 7.96 & -2.25 & 4.79 \\
\hline Plant Disease & 4.34 & 8.07 & 10.71 & 1.23 & 4.66 \\
\hline Grain type & 3.11 & -0.33 & 78.73 & -2.43 & 5.00 \\
\hline Yield & -3.47 & 0.41 & 4.73 & 26.24 & 4.13 \\
\hline \multirow[t]{2}{*}{$\Sigma \mathrm{Z}$} & 14.39 & 4.24 & 45.67 & 12.75 & 8.93 \\
\hline & \multicolumn{5}{|c|}{ Mean value of the generations/sowing time } \\
\hline Plant architecture & 18.05 & 0.42 & 3.53 & 0 & 4.60 \\
\hline Plant Disease & 4.52 & 1.04 & -2.42 & 0 & 3.24 \\
\hline Grain type & -2.94 & -0.21 & 51.05 & 0 & 2.13 \\
\hline Yield & 4.01 & 0.26 & 1.17 & 0 & 3.75 \\
\hline$\Sigma Z$ & 12.86 & 0.62 & 19.55 & 0 & 6.15 \\
\hline
\end{tabular}

this trait, when all the progenies were involved, the $\mathrm{h}^{2}$ was equal to zero. This is another indication of the advantage of the use of the $\Sigma \mathrm{Z}$ index when the goal is the selection of progenies that combine genotypes favorable to several traits. Therefore, selection of populations using the index based on the sum of standardized variables is efficient in identifying those populations that allow superior progenies to be obtained.

\section{Acknowledgments}

To the Coordination for the Improvement of Higher Level Personnel - CAPES for granting a scholarship and to the Brazilian National Council for Scientific and Technological Development - CNPq for research productivity scholarships.

\section{References}

Abreu, A.F.B.; Ramalho, M.A.P.; Santos, J.B. 2002. Prediction of seed yield potential of commom bean populations. Genetic and Molecular Biology 25: 323-327.

Abreu, A.F.B.; Ramalho, M.A.P.; Carneiro, J.E.S.; Del Peloso, M.J.; Paula Júnior, T.J.; Faria, L.C.; Melo, L.C.; Barros, E.G.; Moreira, M.A.; Pereira Filho, I.A.; Martins, M.; Santos, J.B.; Rava, C.A.; Costa, J.G.C.; Sartorato, A. 2007. BRS Majestoso: another common bean cultivar of carioca grain type for the state of Minas Gerais. Crop Breeding And Applied Biotechnology 7: 403-405.

Baenziger, P.S.; Peterson, C.J. 1991. Genetic variation: its origin and use for breeding self-pollinated species. p. 69-100. In: Stalker, H.T.; J.P. Murphy, eds. Plant breeding in the 1990s. Raleigh, NC, USA.
Barbosa, F.R.; Gonzaga, A.C. 2012. Technical Information for Growing Common Bean in the Central Brazilian Region: 2012-2014 = Informações Técnicas para o Cultivo do Feijoeiro-Comum na Região Central Brasileira: 2012-2014. Santo Antônio de Góias, GO, Brazil. (Documentos, 272) (in Portuguese).

Bernardo, R. 2010. Breeding for Quantitative Trains in Plants. 2ed. Stemma Press, Woodbury, MN, USA.

Fouilloux, G.; Bannerot, H. 1988. Selection methods in the common bean (Phaseolus vulgaris L.). p. 503-541. In: Geps, P. Genetic resources of Phaseolus beans. Kluwer Academic, Dordrecht, Netherlands.

Griffing, B. 1956. Concept of general and specific combining ability in relation to diallel erosing systems. Australian Journal of Biological Science 9: 463-493.

Jinks, J.L.; Pooni, H.S. 1976. Predicting the properties of recombinant inbred lines derived by single seed descent. Heredity 36: 253-266.

Johnson, R.A.; Winchern, D.W. 1998. Applied Multivaried Statistical Analysis. Prentice Hall, NJ, USA.

Lima, L.K.; Abreu, A.F.B.; Ramalho, M.A.P. 2012. Implications of the progeny $x$ environment interaction in selection index involving characteristics of the common bean. Genetic and Molecular Research 11: 4093-4099.

Melo, L.C.; Del Peloso, M.J.; Pereira, H.S.; Faria, C.F.; Costa, J.G.C.; Díaz, J.L.C.; Rava, C.A.; Wendland, A.; Abreu, A.F.B. 2010. BRS estilo: common bean cultivar with Carioca grain, upright growth and high yield potential. Crop Breeding and Applied Biotechnology 10: 377-379.

Nienhuis, J.; Singh, S.P. 1988. Genetic of seed yield and its components in common bean (Phaseolus vulgaris L.) of MiddleAmerican origins. I. General combining ability. Plant Breeding 101: 143-154. 
Pereira, H.S.; Wendland, A.; Melo, L.C.; Del Peloso, M.J.; Faria, L.C.; Costa, J.G.C.; Nascente, A.S.; Díaz, J.L.C.; Carvalho, H.L.; Almeida, V.M.; Melo, C.L.P.; Costa, A.F.; Posse, S.C.P.; Souza, J.F.; Abreu, A.F.B.; Magaldi, M.C.S.; Guimarães, C.M.; Oliveira, J.P. 2012. BRS Notável: a medium-early-maturing, disease-resistant Carioca common bean cultivar with high yield potential. Crop Breeding and Applied Biotechnology 12: 220-223.

Ramalho, M.A.P.; Abreu, A.F.B.; Nunes, J.A.R.; Santos, J.B. 2012. Applications of Quantitative Genetics in the Breeding of Autogamous Plants = Aplicações da Genética Quantitativa no Melhoramento de Plantas Autógamas. UFLA, Lavras, MG, Brazil (in Portuguese).

Rasmusson, D.C.; Phillips, R.L. 1997. Plant breeding progress and genetic diversity from de novo variation and elevated epistasis. Crop Science 37: 303-310.
Scott, A.; Knott, M. 1974. Cluster-analysis method for grouping means in analysis of variance. Biometrics 30: 507-512.

Singh, S.P. 1995. Selection for water-stress tolerance in interracial populations of common bean. Crop Science 35: 118-124.

Singh, S.P.; Urrea, C.A. 1995. Inter- and intraracial hybridization and selection for seed yield in early generations of common bean, Phaseolus vulgaris L. Euphytica 81: 131-137.

Steel, R.G.D.; Torrie, J.H.; Dickey, D.A. 1997. Principles and Procedures of Statistics: A Biometrical Approache. 3ed. McGraw-Hill, New York, NY, USA.

Torga, P.P.; Melo, P.G.S; Pereira, H.S.; Faria, L.C.; Del Peloso, M.J.; Melo, L.C. 2013. Interactions of common beans cultivars of the black group with years, locations and sowing seasons. Euphytica 189: 239-248.

Wricke, G.; Weber, W.E. 1986. Quantitative Genetics and Selection in Plant Breeding. Walter de Gruyter, New York, NY, USA. 